\title{
Diatom, silicoflagellate and ebridian biostratigraphy and paleoceanography in IODP 323 Hole U1343E at the Bering slope site
}

\author{
Teraishi, A. ${ }^{1}$, Suto, I. ${ }^{1}$, Onodera, J. ${ }^{2}$, and Takahashi, K. ${ }^{3}$
}

\begin{abstract}
Author Information
${ }^{1}$ Department of Earth and Planetary Sciences, Graduate School of Environmental Studies, Nagoya University, Furo, Chikusa, Nagoya, Aichi 464-8601, Japan

${ }^{2}$ Research Institute for Global Change, Japan Agency for Marine Earth Science and Technology, Natsushima-cho 2-15, Yokosuka, 237-0061, Japan

${ }^{3}$ Laboratory of Paleoenvironmental Science, Department of Earth \& Planetary Sciences, Graduate School of Sciences, Kyushu University, Hakozaki 6-10-1, Higashi-ku, Fukuoka, 812-8581, Japan
\end{abstract}

\section{Corresponding author}

cassette_tape_story@yahoo.co.jp

Tel: +81-52-789-2535

\section{Keywords}

IODP Expedition 323 Hole U1343E, Bering Sea, Pleistocene-Pliocene, diatoms, silicoflagellate, ebridian, paleoceanography, biostratigraphy

25 pages of text, 6 figures and 1 table with 4 appendix tables 
Teraishi et al.

\begin{abstract}
Integrated Ocean Drilling Program (IODP) Expedition 323 was dedicated to reconstruct the details of the Pliocene-Pleistocene paleoenvironmental conditions of the Bering Sea. In this study, fossil diatom assemblages from Hole U1343E were investigated to define diatom biostratigraphy and reveal paleoceanography of the Bering slope region throughout Pleistocene. As the results, four diatom zones with Neogene North Pacific Diatom zone codes (NPD) were determined from the Neodenticula seminae Zone (NPD 12) to the N. koizumii Zone (NPD 9). Diatom biohorizons defined in this study closely correspond with onboard data, but the distinct difference is recognized at the top of the N. koizumii. Additional four biostratigraphic zones estimated by three silicoflagellate and one ebridian datums suggest the core sediment age younger than $2.5 \mathrm{Ma}$. The fluctuations of several paleoenvironmental diatom indicators show that cold conditions with sea-ice existed throughout the duration of the interval studied as well as sea ice expansion occurred at ca. 1.9 Ma and ca. 0.9 Ma. Moreover, increases of neritic diatom species reveal a drop in sea level. Neodenticula seminae is the diatom tracer of the Aleutian Current and hence the decrease of this taxon suggests decrease in inflow of the North Pacific water mass. Although the sea levels must have been dropped during the cold time interval, the consistent occurrences of $N$. seminae indicate that the surface water circulation in the Bering Sea was significantly influenced by the Alaskan Stream at ca. $1.9 \mathrm{Ma}$. On the other hand, during the other cooling event at ca. $0.9 \mathrm{Ma}$, which corresponds to the mid Pleistocene transition (MPT) event, an increase of neritic diatom species and decrease of $N$. seminae were observed. This suggests that coastal environmental conditions accompanied the sea level drop and that the inflow from the North Pacific was weakened. The increases of sea-ice and neritic diatom species suggest that the sea ice and coastal conditions were developed after the cooling at $0.9 \mathrm{Ma}$. The ages at remarkable changes of silicoflagellate assemblages correspond to the ages of global climate shifts at ca. 1.4 Ma, 1.25 Ma, and 0.8-0.9 Ma. The unusual alternate dominances of Distephanus medianoctisol in glacial and Dictyocha species in interglacial periods during the 1.25-0.8 Ma interval suggest the north-south migration of water masses between the Bering Sea and the Subarctic North Pacific.
\end{abstract}


Teraishi et al.

\section{Introduction}

The rate and regional expression of recent global warming are difficult to understand and even more difficult to predict. Recent warming of the high latitudes in the Northern Hemisphere is presumably related to sea ice albedo feedback and teleconnections to other regions (Solomon et al., 2007). Of these regions, the Bering Sea has been considered as important one which significantly affects global climate changes in Pliocene-Pleistocene (Takahashi et al., 2011; Expedition 323 Scientists, 2011a). Therefore, it is pertinent to study both the behavior of sea-ice-climate interactions and the role of large-scale atmospheric and oceanic circulations during such climate changes with geologic records in hand from the Bering Sea. However, little is known about the climate history of the Bering Sea except for several piston core studies mainly focused on the last glacial-interglacial cycle (e.g., Nakatsuka et al., 1995; Gorbarenko, 1996; Cook et al., 2005; Katsuki and Takahashi, 2005; Okazaki et al., 2005; Tanaka and Takahashi, 2005; Takahashi et al., 2005; Brunelle et al., 2007).

Integrated Ocean Drilling Project (IODP) Expedition 323 was dedicated to examine the Pliocene-Pleistocene paleoenvironmental conditions of the Bering Sea; the drilling cruise took place during 5 July to 4 September 2009 (Takahashi et al., 2011) (Fig. 1). During the Expedition, drilling was performed at seven sites covering three different areas: Umnak Plateau (Site U1339), Bowers Ridge (Sites U1340, U1341, and U1342) and the Bering Sea shelf (Sites U1343, U1344, and U1345) regions. Site U1343, which is the main research focus of this study, is located at Bering Sea shelf region called the "Green Belt" because of its high biological productivity (Springer et al., 1996). The Green Belt is formed by the Bering Slope Current (BSC) that originates from the Alaskan Stream water that flows into the Bering Sea through the western Aleutian Islands from the North Pacific. Along the BSC, tidal currents cause strong vertical mixings of the water masses, enhancing biological productivity within the Green Belt. This site is also located close to the maximum extent of today's seasonal sea-ice cover. Thus, this site must have been affected by the fluctuation of ice cover with seasonal or perennial sea-ice during the cold periods such as glacial intervals.

Samples recovered from Hole U1343E $\left(57^{\circ} 33.3814^{\prime} \mathrm{N}, 175^{\circ} 48.9974\right.$ 'W, water depth $1956.0 \mathrm{~m}$, total core length $700.27 \mathrm{~m}$ ) were investigated to define the biostratigraphic datums and acquire the basic data for the paleoceanographic changes in the Bering Sea from the Pliocene to Pleistocene. The analyses were conducted for 'normal' diatom (i.e., diatoms except for Chaetoceros resting spores) and shallow-marine diatom genus Chaetoceros resting spore assemblages as well as silicoflagellate and ebridian group in this study. 
Teraishi et al.

\section{Materials and Methods}

A duplicate pair of one hundred fifty-four microslides prepared for diatom, silicoflagellate and ebridian analyses contained abundant and well-preserved fossil diatom, resting spore, silicoflagellate and ebridian assemblages. To prepare the microslides, silty to clayey sediments containing diatoms were selected ranging from Hole U1343E Cores 323-U1343E-1H-3W, 146-148 cm (top depth: $4.46 \mathrm{~m}$, uncompressed core depth below seafloor (CSF-A), $7.95 \mathrm{~m}$ uncompressed core composite depth (CCSF-A)) and 83X-5W, 146-148 cm (741.71 m CSF-A, 777.34 m CCSF-A). Samples were picked every 3 or $6.5 \mathrm{~m}$ (11 and $25 \mathrm{kyr}$ temporal resolution on average) for the 0 to $1.6 \mathrm{Ma}$, interval which had earlier been defined onboard and every 3 or $6.5 \mathrm{~m}$ ( 5 and $11 \mathrm{kyr}$ resolution) for the 1.6 to $2.2 \mathrm{Ma}$ interval (Takahashi et al., 2011), respectively.

For standard diatom analysis, ca. $0.5 \mathrm{~g}$ of each wet sample was processed, and the methods of sample preparation, counting, and other procedures that we followed are basically the same as those of Koizumi $(1968)$ and Akiba $(1982,1986)$ with a minor modification. The detailed methods for slide preparations and diatom observation are as followed:

Broken materials into powder and approximately $0.5 \mathrm{~g}$ were separated for treatment and dropped in the boiling hydrogen peroxide solution $\left(\mathrm{H}_{2} \mathrm{O}_{2}, 10\right.$ to $\left.15 \%\right)$ already made in $200 \mathrm{ml}$ beaker; the aggregates were decomposed and the organic matter oxidized. Upon cooling, hydrochloric acid ( $\mathrm{HCl}, 25 \%)$ was added to make an acid solution that was then boiled to dissolve the calcium salts in the sample. Afterwards, the beaker was filled with distilled water and allowed to stand for 24 hours. Then, the residue was separated by decanting off the acid water in the beaker. This process was repeated 3 times. In order to remove clay fractions, $50 \mathrm{ml}$ of distilled water was stirred into residue and a solution on peptizer $\left(\mathrm{Na}_{4} \mathrm{P}_{2} \mathrm{O}_{7}, 0.01 \mathrm{~N}\right)$ was added to the beaker, which was allowed to stand for 5 hours. Heavy fractions that contained diatoms deposited and suspension that contained clay grains became white in this process. The residue was separated with decanting off the water in the beaker. The beaker was filled with water solution of peptizer $\left(\mathrm{Na}_{4} \mathrm{P}_{2} \mathrm{O}_{7}, 0.01 \mathrm{~N}\right)$ again. This process was repeated until the supernatant liquid became clean. This decantation separates diatoms, other siliceous fossils including silicoflagellates and ebridians, and unbroken coarser fractions in the suspensions. The remaining residue contained diatoms, other siliceous fossils and unbroken coarser mudstone fragments.

Slides for LM examination were prepared from the cleared sample in the following way. $100 \mathrm{ml}$ of boiling distilled water was added to the cleaned sample and $0.7 \mathrm{ml}$ of the suspension in the beaker was settled by $0.7 \mathrm{ml}$ pipet for some seconds on an $18 \times 18 \mathrm{~mm}$ cover glass and heated in 50 to $60 \stackrel{\circ}{\mathrm{C}}$ for one hour and then mounted on a slide glass using 
Teraishi et al.

Pleurax.

Counting methods for vegetative cell valves of 'normal' diatom and Chaetoceros resting spores were followed after Akiba (1986) and Suto (2006a), respectively. A single vegetative cell valve is counted as one when greater than a half of a valve is observed. Other criteria for identification of specific genera are used following after Akiba (1986) and Akiba and Yanagisawa (1986). Broken specimens of pennales species are counted as one valve when two apices are observed.

Since the relationship between fossil resting spores and extant vegetative cells is not known, the concept of the morpho-species and -generic names are used for fossil Chaetoceros resting spores according to Article 3.3 of the International Code of Botanical Nomenclature (McNeill et al., 2006) in this study. Chaetoceros resting spores possess the characteristic feature of a single ring of puncta at the base of their hypovalve mantles (Suto, 2003), therefore we can easily differentiate hypovalves from epivalves both in extant and fossil material. The methods of Chaetoceros resting spore morpho-species and -genera identification follow those of Suto (2003, 2004a-e, 2005a-c, 2006b-c, 2007). However, some Chaetoceros species have common characteristics on the valve surfaces such as knobs and short spines (i.e. Xanthiopyxis type A (knobbly type); $X$. type B (short spiny type); $X$. type C (long spiny type); hyaline epi/hypovalves; hyaline, knobby and spiny type central vaulted epi/hypovalves). Moreover, several species possess undistinguishable valves (i.e., epivalves of Dispinodiscus pilusus varieties, hypovalves of Gemellodiscus caveatus and G. micronodosus, and valves of $X$. hirsuta and epivalve of $G$. micronodosus). These similarities made it difficult to identify certain species; therefore these unknown valves were not included in the species richness tally.

Diatom abundance is expressed as an approximate number of diatom valves per slide calculated using the length of scanning lines. To determine the fluctuation of diatom and resting spore assemblages, 400 vegetative valves of 'normal' diatoms and 100 Chaetoceros resting spores valves were counted at species level for each sample. After counting, the slides were scanned to record the presence of species missed in the original tally. The resting spore abundance is defined here as the number of spore valves encountered during a count of 400 vegetative cell valves of other diatom species.

Depending on the content of lithogenic materials, the analyzed sample volume for analyses of silicoflagellate and ebridian assemblages was adjusted from 14.9 to 50.1 dry $\mathrm{mg}$ (Mean = $26.5 \mathrm{mg}, 1 \mathrm{SD}=9 \mathrm{mg}$ ). The membrane filter slides for coarse grains (>20 $\mu \mathrm{m}$ size fraction) were made by the same method of Onodera et al. (in this volume). Under light microscope with $\times 200$ and $\times 400$ magnifications, all encountered specimens were counted and identified at species or genus level. In addition, small size fraction was also observed for the 
Teraishi et al.

samples around the datum event depth of tiny species.

In diatom biostratigraphic assignments, ages for diatom bioevents that define zones or characterize certain horizons are based on the western North Pacific diatom zonation by Barron and Gladenkov (1995) and Yanagisawa and Akiba (1998). Taxonomy and biostratigraphic zones for silicoflagellates and ebridians are based on Bukry (1973) and Ling (1973, 1977, 1992). The latest age model at Site U1343 provided by Asahi et al. (in this volume) is used and fitted with diatom and silicoflagellate biostratigraphy as the precise core datums in this paper.

\section{Results}

\subsection{Diatoms}

All samples from Hole U1343E that contained sufficient diatoms per slide ( $>400$, usually nearly 1,000 valves) and Chaetoceros resting spores ( $>100$, usually nearly 400 valves) were investigated in order to refine the sedimentary ages which were initially assigned onboard (Expedition 323 Scientists, 2011b) and to reconstruct the paleoceanographic conditions by diatom assemblage analysis. The preservation and abundance of fossil diatoms are good and common to abundant throughout all microslides, although abundance of Chaetoceros resting spores is rare to common (Appendix tables 1, 2). Diatom assemblages are mostly composed of useful biostratigraphic markers with continuous and abundant occurrences (Fig. 2, Table 1) and several paleoceanographic indicators; cold-water, temperate-water, sea-ice species as well as the taxa living in neritic, open and fresh-waters (Figs. 3-5).

\subsubsection{Diatom biostratigraphy}

Core materials from IODP Expedition 323 Hole U1343E investigated in this study correspond to four diatom zones with the Neogene North Pacific Diatom zone codes (NPD) of Yanagisawa and Akiba (1998), the Neodenticula seminae (NPD 12; 0.0-0.3 Ma), Proboscia curvirostris (NPD 11; 0.3-0.9 Ma), Actinocyclus oculatus (NPD 10; 0.9-(2.0-2.2) Ma) and N. koizumii (NPD 9; (2.0-2.2)-(2.6-2.7) Ma) Zones (Fig. 2). The last occurrence (LO) datums of Proboscia curvirostris (Jousé) Jordan et Priddle and Thalassiosira jouseae Akiba are recognized between Samples 323-U1343E-7H-3W, 141-143 cm and 7H-5W, 136-138 $\mathrm{cm}(61.47 \pm 1.46 \mathrm{~m}$ CSF-A, $70.29 \pm 1.46 \mathrm{~m}$ CCSF-A), giving an age of $0.3 \mathrm{Ma}$ (Barron and Gladenkov, 1995; Yanagisawa and Akiba, 1998). The interval between the top of Hole 
Teraishi et al.

U1343E and the LO of $P$. curvirostris is assigned to the N. seminae Zone (NPD 12) of Yanagisawa and Akiba (1998). The LO datum of Actinocyclus oculatus Jousé (0.9 Ma) is observed between Samples 323-U1343E-33H-5W, 146-148 cm and 34H-3W, 146-148 cm (282.65 $\pm 3.97 \mathrm{~m}$ CSF-A, 318.27 $\pm 3.97 \mathrm{~m}$ CCSF-A). The interval between this datum level and the LO of $P$. curvirostris is assigned to $P$. curvirostris Zone (NPD 11). The interval below this datum and above the LO of $N$. koizumii Akiba et Yanagisawa is A. oculatus Zone (NPD 10). In addition, the first occurrence (FO) of $P$. curvirostris $(1.7 \mathrm{Ma})$ is defined between Samples 323-U1343E-55X-3W, 146-148 cm and 55X-5W, $132-134 \mathrm{~cm}(471.60 \pm 1.44 \mathrm{~m}$ CSF-A, 507.22 $\pm 1.44 \mathrm{~m}$ CCSF-A), and the LO of Stephanopyxis horridus Koizumi (1.9 Ma) is also observed between Samples 323-U1343E-60X-5W, 130-133 cm and 61X-3W, 146-148

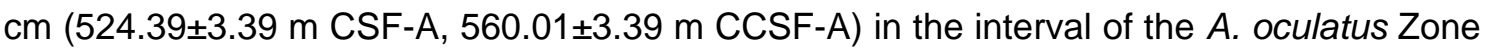
(NPD 10). In the deeper Hole U1343E, the LO of N. koizumii is estimated between Samples

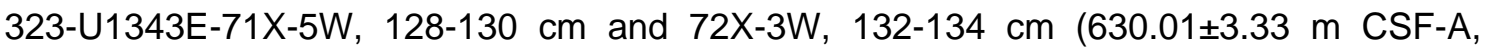
$665.63 \pm 3.33 \mathrm{~m}$ CCSF-A), assigning an age of $2.1 \mathrm{Ma}$ (Yanagisawa and Akiba, 1998). The absence of a biostratigraphic maker species $N$. kamtschatica indicates that the interval between this datum and the bottom of Hole U1343E can be assigned to the $N$. koizumii Zone (NPD 9).

With respect to the shipboard age data (Expedition 323 Scientists, 2011b), the diatom biohorizons defined by several diatom zones in this study correspond closely to those of the shipboard results, however a distinct difference is recognized at the top of the $N$. koizumii Zone. Although the LO of $N$. koizumii was observed at $680.8 \mathrm{~m}$ CSF-A ( $=714.42 \mathrm{~m}$ CCSF-A) at the onboard data, the biohorizon is recognized in the upper part $(633.33 \mathrm{~m}$ CSF-A, $668.95 \mathrm{~m}$ CCSF-A) in this study. Compare to the age model provided by Asahi et al. (in this volume), the LO of $A$. oculatus and the $\mathrm{FO}$ of $P$. curvirostris were recognized in lower and upper parts, respectively.

\subsubsection{Diatom paleoenvironmental indicators}

In this study, 110 species of vegetative cell valves of 'normal' diatoms are observed. Figure 3 shows the relative abundance (\%) of selected paleoenvironmental indicators in diatom assemblages from Hole U1343E. Most diatom species observed in this study are marine planktonic ones, but a few fresh water species are observed sporadically: Achnanthes inflata (Kützing) Grunow, A. lanceolata (Brébisson ex Kützing) Grunow in Cleve et Grunow, A. lineariformis Lange-Bertalot, Amphora ovalis var. libyca (Ehrenberg) Cleve, Aulacoseira granulata (Ehrenberg) Simonsen, Caloneis westii (W. Smith) Hendey, Cyclotella meneghiniana Kützing, Cymbella cistula (Hemprich in Hemprich et Ehrenberg) Kirchner, $C$. 
Teraishi et al.

subaequalis Grunow in Van Heurck, Eunotia pectinalis var. minor (Kützing) Rabenhorst, E. praerupta var. praerupta Ehrenberg, Fragilaria construens (Ehrenberg) Grunow, Navicula elginensis (Gregory) Ralfs in Pritchard, N. menisculus Schumann, N. salinarum Grunow, and Reimeria sinuata (Gregory) Kociolek et Stoermer.

Marine diatoms are divided into five groups: cold-water, temperate-water, sea-ice related, neritic and open-ocean species. Figure 3 shows relative abundances (\%) of these paleoceanographic indicators in total occurrences of vegetative cells as well as occurred valve numbers of Chaetoceros resting spores. Several indicators are included as follows:

Cold-water species: Actinocyclus ochotensis Jousé, Bacterosira bathyomphala (P.T. Cleve) Syvertsen et Hasle in Hasle et Syvertsen, Coscinodiscus oculus-iridis Ehrenberg, Neodenticula seminae (Simonsen et Kanaya) Akiba et Yanagisawa, Porosira glacialis (Grunow) E. Jørgensen, Rhizosolenia hebetata J.W. Bailey, Shionodiscus trifultus (G. Fryxell) Alverson et al. (= Thalassiosira trifulta G. Fryxell in Fryxell et Hasle), Thalassiosira hyalina (Grunow in Cleve et Grunow) Gran, T. nordenskioeldii Cleve and T. sancettae Akiba (after Sancetta, 1982; Medlin and Priddle, 1990).

Sea-ice related species: $B$. bathyomphala, Fragilariopsis cylindrus (Grunow) Frenguelli, $T$. hyalina, and resting spores of Thalassiosira antarctica Comber (after Expedition 323 Scientists, 2011b).

Temperate-water species: Thalassiothrix spp. and Stephanopyxis spp. (after Sancetta, 1982; Hasle and Syvertsen, 1996).

Neritic species: B. bathyomphala, Paralia sulcata (Ehrenberg) Cleve, Porosira gracialis (Grunow) Cleve and T. hyalina (after Sancetta, 1982; Medlin and Priddle, 1990).

Open-ocean species: A. ochotensis, R. hebetata and S. trifultus (after Sancetta, 1982).

In Expedition 323 Scientists (2011b), Bacterosira bathyomphala which showed the characteristic changes at 0.8 and $1.1 \mathrm{Ma}$ were contained as sea-ice related species, and these transitions were predicted to be affected by the mid-Pleistocene transition (MPT). In this study, higher resolution samples than those used in onboard study were used to reveal the effect of the MPT in more detail. Therefore, Bacterosira bathyomphala were classified to sea-ice related species. Moreover, Stephanopyxis spp. may be strongly affected by the sea surface temperate water (Sancetta, 1982) although they are also mentioned dwelling taxa that are transported to deeper waters. Therefore, Stephanopyxis spp. were not treated as neritic nor open-water species in this study.

Cold-water and sea-ice related species occur at high-abundances throughout the hole. Increased abundances of cold-water species are observed at ca. $1.9 \mathrm{Ma}$ and ca. 1.2 $\mathrm{Ma}$ and those of sea-ice related species are recognized at ca. $1.9 \mathrm{Ma}$ and ca $0.9 \mathrm{Ma}$ (Fig. 3). The temporal decrease of cold-water species is observed after ca. 1.1 Ma. After the de- 
Teraishi et al.

crease, the relative abundance of cold-water species remains at nearly the same level, but the abundance of sea-ice related species shows a gradual increasing trend. On the other hand, the drastic decrease of temperate-water species is recognized at ca. $1.9 \mathrm{Ma}$ with the periodic changes in abundance before the decreasing event. Occurrences of neritic and open-ocean species show gradual increases from the bottom to the top.

\subsubsection{Abundance of Chaetoceros resting spores and species diversity}

Figure 3 also shows the stratigraphic abundance changes of Chaetoceros resting spores as observed valve numbers during counting routine of 400 vegetative cell valves. Abundances of Chaetoceros resting spores in most samples are common and the valve numbers exceed from 100 to 300 , although some samples show low abundances.

Species diversity of resting spores shows slight variation, but rapid decrease of Gemellodiscus cingulus var. longus Suto and drastic increase of $G$. cingulus var. cingulus Suto are recognized in Sample 323-U1343E-53X-3W, 146-148 cm (450.87 m CSF-A, $486.49 \mathrm{~m}$ CCSF-A). Although no distinct change in the morpho-generic level was observed, the abundance of Dispinodiscus spp. appears to increase gradually towards the upper section. The ecology of fossil and extant resting spores is unclear except for some species (e.g., Oku and Kamatani, 1999), however, the fluctuation of Chaetoceros has been interpreted as a measure of diatom productivity and indicator of the extent of upwelling with high nutrient supply (Sancetta, 1982; Suto, 2006a). Therefore, the fluctuation of Chaetoceros assemblages and abundance likely shows environmental conditions regarding nutrients.

\subsection{Skeleton contents of silicoflagellate and ebridian}

Total silicoflagellate and ebridian contents are usually very low throughout the hole (Figs. 4, 6, Appendix table 3). The silicoflagellate contents ranged from 0 to $256.8 \times 10^{3}$ skeletons dry $\mathrm{g}^{-1}$ (mean $=8.4 \times 10^{3}, 1 \mathrm{SD}=29.6 \times 10^{3}$, median $=1.3 \times 10^{3}$ skeletons dry $\mathrm{g}^{-1}, \mathrm{~N}=$ 154). The large fluctuation of silicoflagellate contents essentially corresponds to glacial-interglacial cycles; with minimal members of silicoflagellate contents usually observed in glacial periods. Their low contents are mainly due to a dilution effect by abundant lithogenic materials. The ebridians are usually observed in the lower part of this hole. The ebridian contents ranged from 0 to $7.3 \times 10^{3}$ skeletons dry $\mathrm{g}^{-1}$ (mean $=0.3 \times 10^{3}, 1 \mathrm{SD}=0.8 \times 10^{3}$, median $=0$ skeletons dry $g^{-1}, \mathrm{~N}=154$ ).

The encountered silicoflagellates and ebridians were categorized to 12 and 5 taxa, respectively (Appendix table 3 ). Silicoflagellates found in this study are similar to those in 
Teraishi et al.

previous studies on DSDP Leg 19 cores (Bukry, 1973; Ling, 1973). Ebridian specimens of genus Ammodochium in this study are probably composed of several subspecies. However, they are here treated as Ammodochium rectangulare group for the comparison with previous studies.

\subsubsection{Silicoflagellate-Ebridian biostratigraphy}

Based on the silicoflagellate and ebridian biostratigraphic zone by Ling (1973), Hole U1343E cores can be categorized into four zones as followed (Fig. 2).

Distephanus octangulatus Zone

The LO of Distephanus octonarius is located between Samples 323-U1343E-5H-3, 146-148 cm and 6H-3, 146-148 cm (45.92 $\pm 4.67 \mathrm{~m}$ CSF-A, 52.82 $\pm 6.28 \mathrm{~m}$ CCSF-A). The upper interval above this datum is assigned to Distephanus octangulatus Zone. Distephanus octonarius Zone

As the bottom of this zone, the LO of Dictyocha subarctios is estimated between Samples 323-U1343E-23H-3, 140-142 cm and 23H-5, 53-55 cm (188.39 $\pm 1.07 \mathrm{~m}$ CSF-A, 215.60 $\pm 1.07 \mathrm{~m}$ CCSF-A). This datum is usually observed just above the Brunhes/Matuyama magnetic boundary (Ling, 1992). However, the depth of LO of Dc. subarctios recognized in this study is deeper than the Brunhes/Matuyama boundary at $181.37 \mathrm{~m}$ CSF-A (207.73 m CCSF-A). The LO of Distephanus crux stauracanthus is also observed between Samples 323-U1343E-19H-5, 96-98 cm and $20 \mathrm{H}-3,121-123 \mathrm{~cm}(157.58 \pm 2.55 \mathrm{~m} \mathrm{CSF}, 180.89 \pm 3.84 \mathrm{~m} \mathrm{CCSF})$.

Dictyocha subarctios Zone

The LO of ebridian Ammodochium rectangulare is located between Samples 323-U1343E-63X-5, 83-85 cm and 64X-3, 146-148 cm (552.55 $\pm 4.12 \mathrm{~m}$ CSF-A, $558.17 \pm 4.12 \mathrm{~m}$ CCSF-A), which is the base of this zone. Although the Sample 323-U1343E-63X-5, 83-85 cm includes one specimen of ebridian Am. rectangulare, it is probably rework component because one specimen of old ebridian Ebriopsis antiqua (LO: $2.5 \mathrm{Ma}$ ) is also observed in the sample. Dictyocha subarctios in this hole mainly occurred in the upper part of this zone. The FO of this taxon in the North Pacific nearly corresponds to that of radiolarian Eucyrtidium matuyamai (Ling, 1976). However, the deepest occurrence of Dc. subarctios in this study is observed at 470.17 m CSF-A (505.79 m CCSF-A) whereas the FO of Eu. matuyamai is estimated at $612.5 \mathrm{~m}$ CSF-A (648.1 m CCSF-A) (Expedition 323 Scientists, 2011b).

Ammodochium rectangulare Zone

Because the LO of Ebriopsis antiqua is not found in this hole, the interval between 
Teraishi et al.

the LO of Ammodochium spp. and Sample 323-U1343E-82X-5, 146-148 cm (732.47 m CSF-A, 768.09 m CCSF-A) is assigned to this zone. Silicoflagellates in this zone are mainly composed of Distephanus speculum. Biostratigraphic zone for Core 83X is not specified due to barren of age indicator species.

\subsubsection{Silicoflagellates paleoenvironmental indicators}

Silicoflagellates older than ca. $1.38 \mathrm{Ma}$ are usually dominated by Distephanus speculum, which is common in cold waters (Poelchau, 1976). The dominant taxon in the assemblages frequently changed in the interval younger than $1.38 \mathrm{Ma}$ (Fig. 6). The high dominance (> about $70-80 \%$ ) of Ds. medianoctisol probably suggests significantly cold condition with sea-ice (Takahashi et al., 2009). The gradual increase of Ds. medianoctisol (\%) since ca. 1.2 Ma suggests the colder sea surface condition in glacial periods. On the other hand, the temporal dominance of Dictyocha subarctios and Dc. spp. (Dc. aff. mandrai ?) in interglacial periods between $1.25 \mathrm{Ma}$ and $0.9 \mathrm{Ma}$ may reflect temperate condition based on the biogeographic studies (Ling, 1976; Poelchau 1976).

\section{Discussion}

\subsection{Diatom-based paleoceanographic discussion at Hole U1343E}

The abundant and steady occurrences of cold-water and sea-ice related diatom species encountered throughout Hole U1343E indicate that the existence of seasonal sea-ice cover with fairly low sea surface temperatures was present during the interval between ca. 2.2 Ma and the present (Fig. 3). The changes in relative abundances of these groups may be related with cyclic climate changes of warm-cold intervals which initially developed since the intensification of the Northern Hemisphere glaciations at 2.7 Ma (Haug et al., 2005).

The drastic decrease of temperate-water species and increase of cold-water and sea-ice related species at ca. 1.9 Ma indicate that the Bering slopes region around Hole U1343E became cooler and covered sea-ice expanded in a short interval. The increase of neritic species observed coincides with the expansion of sea-ice and may suggest that the basin around this hole became shallower and/or more typical of coastal environmental conditions corresponding with a sea level regression coinciding with global cooling. Katsuki et al. (2004) mentioned that the continental shelf was exposed to the air when the sea level dropped the $50 \mathrm{~m}$. Therefore, the emergence of the continental shelves may be happened 
Teraishi et al.

at the cooling of ca. $1.9 \mathrm{Ma}$.

The relative abundance of Neodenticula seminae, which is considered as a good tracer for the relative warm Alaskan stream from the North Pacific (Sancetta, 1982), remained at higher levels throughout the hole. This coincided with a decrease of temperate-water species at $1.9 \mathrm{Ma}$ and increases of cold-water, sea-ice related and neritic species during several intervals (Fig. 3). When the eastern passes in the Aleutian Arc became closed during the low sea-level stands, the abundance of $N$. seminae must have decreased due to weakening of the entry of the Alaskan Stream water mass. Therefore, the consistent occurrences of $N$. seminae suggest that the oceanic circulation in the Bering Sea was at times strongly influenced by the Alaskan Stream, which entered the Bering Sea through the passes in the Aleutian Arc (Stabeno et al., 1999), similar to the circulation occurring during the last glaciation (Katsuki and Takahashi, 2005) (Fig. 1). It also indicates that waters above the Bering slope site became cooler and shallower while the North Pacific water was supplied from the Aleutian passes.

The increases of cold-water and sea-ice related species observed at $0.9 \mathrm{Ma}$ correspond to the middle Pleistocene transition (MPT) which is characterized by a severe increase of glaciations starting at $1.25 \mathrm{Ma}$ (Clark et al., 2006). The transition to glacial period was also well-known to change from $41-k y r$ cycle to $100-k y r$ cycle in ocean temperature around the age. Lisiecki and Raymo (2005) also showed it as the cyclic changes of the Marine Isotope Stages (MISs) constructed stacked by the benthic foraminiferal $\delta^{18} \mathrm{O}$ records conducted by averaging 57 globally distributed sites. The maximum glaciation was established at ca. 0.7 Ma with the dominant 100-kyr cycles and the minimum value of the sea surface temperature (SST) was observed at $0.9 \mathrm{Ma}$ in the North Atlantic from DSDP Leg 94 Site 607 (Clark et al., 2006). On the other hand, the minimum SST was not observed from ODP Leg 145 Site 882 in the North Pacific region (McClymont et al., 2008). Moreover, Sancetta and Silvestri (1986) showed by the cluster analysis of diatom assemblages that much of the low temperature and salinity waters which consisted of the Okhotsk water. The increase of cold-water species and peak of sea-ice related taxa at ca.1.25 to $0.9 \mathrm{Ma}$ recognized in this study might be affected by the global cooling of the MPT. The continuous increase of sea-ice related species, gradual increase of neritic taxa and relatively low abundance of $N$. seminae observed after the MPT indicate that the cooling and restricted pelagic water entry with regression were caused by closure of the Aleutian Arc passes. Therefore, the extent of the Bering surface water mass circulation appears to have become weaker after the MPT.

As Chaetoceros resting spores are severely affected by environmental fluctuations, such as nutrient supplied by upwelling in the coastal region, their abundances must have 
Teraishi et al.

been changed by environmental changes such as alternation of eutrophication and oligotrophication or the variations of the clastic grain and microelements supplies from the land (Sancetta, 1982; Suto, 2006a). The continuous and abundant occurrence of Chaetoceros resting spores from Hole U1343E indicate that the region around this hole retained high-nutrient and/or active upwelling environmental conditions during low-nutrient seasons when Chaetoceros produced resting spores throughout the Pleistocene. Some peaks of the neritic and fresh water species in some samples may indicate that this hole was affected by some input of river water flowing into the Bering Sea coinciding with sea-level fall. But during these peaks, no drastic changes were observed in other species, suggesting that the effect of river water might be very weak.

\subsection{Silicoflagellate-based paleoceanographic discussion at Hole U1343E}

The most unusual characteristic of silicoflagellate assemblages in this study is the common occurrence of Dictyocha spp. at $1.085 \mathrm{Ma}$ (Fig. 6), because Dictyocha species are mainly observed in subtropical-temperate waters (e.g., Poelchau, 1976). Even in the modern Bering Sea, the relative abundance of Dictyocha spp. in the total silicoflagellate assemblage is less than 1\% during August 1990-June 1994 (Onodera and Takahashi, 2012). On the other hand, the modern silicoflagellates in the eastern subarctic North Pacific show seasonal dominance of Dictyocha mandrai (Takahashi, 1987). In addition, the relative abundance of Dictyocha in the modern Western Subarctic Gyre is less than 15\% (Onodera and Takahashi, 2005). Thus, the eastern subarctic Pacific waters are considered as the possible origin of water mass with abundant Dictyocha at $1.085 \mathrm{Ma}$ in this study. This age corresponds with deglacial conditions from MIS32 to MIS31. The "super-interglacial" event at MIS31 has been suggested by core study (Scherer et al., 2008; Naish et al., 2009) and model study (Pollard and DeConto, 2009) in the Antarctic. The global sea-level in MIS31 might be $>5 \mathrm{~m}$ higher than today's level due to the large collapse of the West Antarctic Ice Sheet (Pollard and DeConto, 2009). The unique warming trend from MIS32 to MIS31 might be the factor for the northward input of Dictyocha species.

The occurrence pattern of Dictyocha subarctios in this study may also reflect the water mass advection from the south of this site. This taxon has been commonly reported from the subarctic Pacific, Bering Sea, and Japan Sea (Ling, 1976), however, their limited common occurrences in interglacial periods from ca. 1.25 Ma to ca. 0.9 Ma (Fig. 6) suggest that the main habitat of Dc. subarctios was in the subarctic Pacific rather than in the northern Bering Sea. The northern limit latitude of Dc. subarctios distribution appears to be lower than that of Neodenticula seminae, because that $N$. seminae in this study is observed even 
Teraishi et al.

in glacial periods. The temporal northern excursion of Dc. subarctios to the Bering Sea at $1.25 \mathrm{Ma}$ is also supported by the first occurrence of $N$. seminae in the Iceland Sea via the Bering Strait at the same timing (Koç and Scherer, 1996).

However, the dominances of Distephanus medianoctisol in glacial periods from about 1.2 Ma to $0.5 \mathrm{Ma}$ suggest the presence of sea-ice at this site or vicinal shelf during the productive seasons of silicoflagellates. The relative abundance of modern Ds. medianoctisol in dense sea-ice area of the summer Arctic Ocean is $>70 \%$ in total silicoflagellates (Takahashi et al., 2009), whereas relative abundance of Ds. medianoctisol in the modern southern Bering Sea is less than 10\% (Onodera and Takahashi, 2012). The northward shift of temperate silicoflagellates in glacial periods was limited under the colder condition.

\section{Conclusions}

A pair of one hundred fifty-four slides from IODP Expedition Hole U1343E, containing greater than 100 species of fossil diatom and resting spore assemblages and several silicoflagellate and ebridian groups, were investigated to define the biostratigraphic datums. Theyn were also employed to acquire the basic data for the paleoceanographic changes in the Bering Sea from the Pliocene to Pleistocene.

As a result, four diatom zones were defined; the Neodenticula seminae (NPD 12: 0.0-0.3 Ma), Proboscia curvirostris (NPD 11: 0.3-0.9 Ma), Actinocyclus oculatus (NPD 10: 0.9-(2.0-2.2) Ma) and N. koizumii (NPD 9: (2.0-2.2)-(2.6-2.7) Ma) Zones as well as the LO datums of Proboscia curvirostris and Thalassiosira jouseae ( $0.3 \mathrm{Ma})$, the FO of $P$. curvirostris (1.7 Ma) and the LO of Stephanopyxis horridus (1.9 Ma). Moreover, four silicoflagellate and ebridian zones are also found, the Distephanus octangulatus Zone $(0-0.2 \mathrm{Ma}$ as defined/nominal), Ds. octonarius Zone $(0.2-0.74 \mathrm{Ma})$, Dictyocha subarctios Zone (0.74-(1.8-2.0) Ma), and Ammodochium rectangulare Zone ((1.8-2.0)-2.5 Ma).

The diatom sea-ice indicators remained at high-abundances throughout the interval investigated from the hole, with the consistent occurrence of cold-water and sea-ice related species corresponding to that of ice rafted debris. On the other hand, an abrupt decrease in temperate-water diatom species is recorded at ca. $1.9 \mathrm{Ma}$. These fluctuations indicate that the existence of seasonal sea-ice during the interval from ca. 2.2 Ma to the present, and that the Bering slopes became cooler and sea-ice expanded in a short interval. After the expansion of sea-ice, the basin became shallower and/or more coastal environment with regression as the result of the global cooling.

The increases of cold-water and sea-ice related diatom species observed at ca. 0.9 Ma might be affected by onset of the MPT. The continuous increase of sea-ice related species, gradual increase of neritic taxa and relatively low abundance of $N$. seminae observed 
Teraishi et al.

after the MPT show that the cooling with global regression caused the closure of the Aleutian Arc passes.

Resting spores of Chaetoceros indicating upwelling and high-nutrient condition show consistent abundance, with the numbers of resting spores exceeding from 100 to 300 in 400 vegetative valves of other "normal" diatoms. The region around this hole, therefore, retained high-nutrient and/or upwelling conditions during low-nutrient season when Chaetoceros produce resting spores throughout the Pleistocene.

Silicoflagellates are usually commonly observed in interglacial periods. Relatively stable sea-surface condition suggested by constant dominance of $D$ s. speculum terminated around 1.4 Ma. The next remarkable change is marked between 1.25 Ma and $0.9 \mathrm{Ma}$ by the alternate dominances of Ds. medianoctisol in glacial and Dictyocha species in interglacial periods. These assemblage changes suggest north-south migration of surface waters between the Bering Sea and the subarctic North Pacific and/or larger fluctuation of sea-surface temperature. However, the sampled interval in this study is still coarse for deciphering paleoceanography in detail. The palaeoceanographic studies in higher resolution are needed for some significant intervals in the future.

\section{Acknowledgments}

Our thanks are extended to especially Prof. Yasufumi Iryu and our colleagues of the Laboratory of Geobiology, Nagoya University for their help and advice. Extended thanks go to Co-Chief Scientist Prof. A. Christina Ravelo and the scientific party of IODP Expedition 323 as well as the captain and crews. We also acknowledge two reviewers, Dr. John A. Barron and Mr. Fumio Akiba, for their invaluable comments to this manuscript. This study used samples and data provided by the Integrated Ocean Drilling Program (IODP). IODP is sponsored by the U.S. National Science Foundation (NSF) and participating countries under the management of the Joint Oceanographic Institutions (JOI) Inc. 


\section{References}

Abbott, W.H., 1980. Diatoms and stratigraphically significant silicoflagellates from the Atlantic Margin Coring Project and other Atlantic Margin sites. Micropaleontology 26(1), 49-80.

Akiba, F., 1982. Taxonomy and biostratigraphic significance of a new diatom, Thalassionema schraderi. Bacillaria 5, 43-61.

Akiba, F., 1986. Middle Miocene to Quaternary diatom biostratigraphy in the Nankai Trough and Japan Trench, and modified Lower Miocene through Quaternary diatom zones for middle-to-high latitudes of the North Pacific. In: Kagami, H., Karig D.E. Coulbourn, W.T., et al. (Eds.), Initial Reports of the Deep Sea Drilling Project 87. US Government Printing Office, Washington, DC, 393-481. doi:10.2973/dsdp.proc.87.106.1986.

Akiba, F., Yanagisawa, Y., 1986. Taxonomy, morphology and phylogeny of the Neogene diatom zonal marker species in the middle-to-high latitudes of the North Pacific. In: Kagami, H., Karig D.E. Coulbourn, W.T., et al. (Eds.), Initial Reports of the Deep Sea Drilling Project 87. US Government Printing Office, Washington, DC, 483-554. doi:10.2973/dsdp.proc.87.107.1986.

Ando, K., 1990. Environmental indicators based on freshwater diatom assemblages and its application to reconstruction of paleo-environments. Annuals of the Tohoku Geographical Association 42. 89-104.

Asahi, H., Kender, S., Ikehara, M., Sakamoto, T., Takahashi, K., Ravelo, A.C., Alvarez-Zarikian, $\mathrm{C}$. in this volume. Oxygen isotope stratigraphy at the Bering Slope (IODP Exp. 323 Site U1343) during last 2.3 Myrs. Deep-Sea Research II.

Barron, J.A., Gladenkov, A.Y., 1995. Early Miocene to Pleistocene diatom biostratigraphy of Leg 145. In: Rea, D.K., Basov, I.A., Scholl, D.W., Allan, J.F. (Eds.), Proceedings of Ocean Drilling Program, Scientific Results 145. Ocean Drilling Program, College Station, TX, 3-19. doi:10.2973/odp.proc.sr.145.101.1995.

Brunelle, B.G., Sigman, D.M., Cook, M.S., Keigwin, L.D., Haug, G.H., Plessen, B., Schettler, G., Jaccard, S.L., Evidence from diatom-bound nitrogen isotopes for subarctic Pacific stratification during the last ice age and a link to North Pacific denitrification changes. Paleoceanography 22, PA1215. doi:10.1029/2005PA001205.

Bukry, D. 1973. Coccoliths and silicoflagellates from Deep Sea Drilling Project Leg 19, North Pacific Ocean and Bering Sea. In: Creager, J.S., Scholl, D.W., et al., (Eds.), Initial Reports of the Deep Sea Drilling Project 19, US Government Printing Office, Washington, DC, 857-867. doi:10.2973/dsdp.proc.19.131.1973.

Bukry, D., Foster, J.H. 1973. Silicoflagellate and diatom stratigraphy, Leg 16, Deep Sea Drilling Project. In: van Andel, T.H., Heath, G.R., et al., Eds., Initial Reports of the Deep 
Sea Drilling Project 16, U.S. Government Printing Office, Washington, DC, 815-871. doi:10.2973/dsdp.proc.16.129.1973.

Clark, P.U., Archer, D., Pollard, D., Blum, J.D., Rial, J.A., Brovkin, V., Mix, A.C., Pisias, N.G., Roy, M., 2006. The middle Pleistocene transition: characteristics, mechanisms, and implications for long-term changes in atmospheric $\mathrm{pCO}_{2}$. Quaternary Science Reviews 25, 3150-3184. doi:10.1016/j.quascirev.2006.07.008.

Cook, M.S., Keigwin, L.D., Sancetta, C.A., 2005. The deglacial history of surface and intermediate water of the Bering Sea. Deep-Sea Research II 52, 2163-2173. doi:10.1016/j.dsr2.2005.07.004.

Creager, J.S., Scholl, D.W., Supko, P.R., 1973. Introduction. In: Creager, J.S., Scholl, D.W. et al. (Eds.), Initial Reports of the Deep Sea Drilling Project 19, US Government Printing Office, Washington, DC, 3-16. doi:10.2973/dsdp.proc.19.101.1973.

Expedition 323 Scientists, 2011a. Expedition 323 summary. In: Takahashi, K., Revelo, A.C., Alvarez Zarikian, C.A., the Expedition 323 Scientists (Eds.), Proceedings of the IODP 323. Integrated Ocean Drilling Program Management International, Inc., Tokyo. doi:10.2204/iodp.proc.323.101.2011.

Expedition 323 Scientists, 2011b. Site U1343. In: Takahashi, K., Revelo, A.C., Alvarez Zarikian, C.A., the Expedition 323 Scientists (Eds.), Proceedings of the IODP 323. Integrated Ocean Drilling Program Management International, Inc., Tokyo. doi:10.2204/iodp.proc.323.106.2011.

Gladenkov, A.Y., 1994. Diatom assemblages from the Pliocene-Pleistocene Boundary beds in Kamchatka, Russia. Micropaleontology 20(1), 79-94.

Gladenkov, A.Y., 2003. Diatom biostratigraphy of the Neogene Milky River Formation, Alaska Peninsula, southwestern Alaska. Proceedings of the California Academy of Sciences 54(3), 27-64.

Gorbarenko, S.A., 1996. Stable isotope and lithologic evidence of late-glacial and Holocene oceanography of the northwestern Pacific and its marginal seas. Quaternary Research 46, 230-250. doi:10.1006/qres.1996.0063.

Hasle, G.R., Heimdal, B.R., 1998. The net phytoplankton in Kongsfjorden, Svalbard, July 1988, with general remarks on species composition of arctic phytoplankton. Polar Research 17(1), 31-52. doi: 10.1111/j.1751-8369.1998.tb00257.x.

Hasle, G.R., Syvertsen, E.E., 1996. Marine diatoms. In: Tomas, C.R. (Ed.), Identifying Marine Phytoplankton. Academic Press, Florida, 5-385.

Haug, G.H., Ganopolski, A., Sigman, D.M., Rosell-Mele, A., Swann, G.E.A., Tiedemann, R., Jaccard, S.L., Bollmann, J., Maslin, M.A., Leng, M.J., Eglinton, G., 2005. North Pacific seasonality and the glaciations of North America 2.7 million years ago. Nature 433, 
Teraishi et al.

821-825. doi:10.1038/nature03332.

Kamikuri, S., Nishi, H., Motoyama, I., 2007. Effects of late Neogene climate cooling on North Pacific radiolarian assemblages and oceanographic conditions. Palaeogeography, Palaeoclimatology, Palaeoecology 249, 370-392. doi:10.1016/j.palaeo.2007.02.008.

Katsuki, K., Takahashi, K., 2005. Diatoms as paleoenvironmental proxies for seasonal productivity, sea-ice and surface circulation in the Bering Sea during the late Quaternary. Deep-Sea Research II 52, 2110-2130. doi:10.1016/j.dsr2.2005.07.001.

Katsuki, K., Takahashi, K., Matsushita, K., 2004. Diatom paleoceanography during the past $340 \mathrm{kyr}$ in the Bering Sea and the western subarctic Pacific. In: Poulin, M. (Ed.), Proceedings of the Seventeenth International Diatom Symposium 2002, Ottawa, Canada, Biopress, Bristol, England, 147-159.

Kellogg, D.E., Kellogg, T.B., 1986. Diatom biostratigraphy of sediment cores from beneath the Ross Ice Shelf. Micropaleontology 32(1), 74-94.

Koç, N., Scheler, R.P., 1996. Neogene diatom biostratigraphy of the Iceland Sea Site 907. In: Thiede, J., Myhre, A.M., Firth, J.V., Johnson, G.L., Ruddiman, W.F., (Eds.), Proceedings of Ocean Drilling Program, Scientific Results 151. Ocean Drilling Program, College Station, TX, 61-74. doi:10.2973/odp.proc.sr.151.108.1996.

Koizumi, I., 1968. Tertiary diatom flora of Oga Peninsula, Akita Prefecture, northeast Japan. Science Report of the Tohoku University, Second Series (Geology) 40, 171-240.

Kosugi, M., 1988. Classification of living diatom assemblages as the indicator of environments, and its application to reconstruction of paleoenvironments. The Quaternary Research 27(1), 1-20 (in Japanese with English abstract).

Ling, H.Y., 1972. Upper Cretaceous and Cenozoic silicoflagellates and ebridians. Bulletins of American Paleontology 62, 135-229.

Ling, H.Y., 1973. Silicoflagellates and ebridians from Leg 19. In: Creager, J.S., Scholl, D.W., et al., (Eds.), Initial Reports of the Deep Sea Drilling Project 19, US Government Printing Office, Washington, DC, 751-775. doi:10.2973/dsdp.proc.19.127.1973.

Ling, H.Y., 1976. Distribution and biostratigraphic significance of Dictyocha subarctios (Silicoflagellate) in the North Pacific. Transactions and proceedings of the Palaeontological Society of Japan. New Series 101, 264-270.

Ling, H.Y., 1977. Late Cenozoic silicoflagellates and ebridians from the Eastern North Pacific region. Proceedings of the First International Congress on Pacific Neogene Stratigraphy, Tokyo 1976, 205-233.

Ling, H.Y., 1992. Late Neogene silicoflagellates and ebridians from Leg 128, Sea of Japan. In: Pisciotto, K.A., Ingle, J.C., Jr., von Breymann, M.T., Barron, J., et al., (Eds.), Proceedings of Ocean Drilling Program, Scientific Results, vol. 127/128 (pt. 1). Ocean 
Drilling Program, College Station, $\quad$ TX, 237-248. doi:10.2973/odp.proc.sr.127128-1.126.1992.

Ling, H.Y., McPherson, L.M., 1974. Study on the ebridian genus Parathranium Hovasse. Revista Española de Micropaleontologia 6, 191-200.

Lisiecki, L.E., Raymo, M.E., 2005. A Pliocene-Pleistocene stack of 57 globally distributed benthic $\delta^{18} \mathrm{O}$ records. Paleoceanography 20, PA1003. doi:10.1029/2004PA001071.

Loeblich, A.R.III., Loeblich, L.A., Tappan, H., Loeblich, A.R.Jr., 1968. Annotated index of fossil and recent silicoflagellates and ebridians with descriptions and illustrations of validly proposed taxa. Geological Society of America. Memoir 106, 319 pp.

McClymont, E.L., Rosell-Mele, A., Haug, G.H., Lloyd, M., 2008. Expansion of subarctic water masses in the North Atlantic and Pacific oceans and implications for mid-Pleistocene ice sheet growth. Paleoceanography 23, PA4214. doi:10.1029/2008PA001622.

McNeill, J., Barrie, F.R., Burdet, H.M., Demoulin, V., Hawksworth, D.L., Marhold, K., Nicolson, D.H., Prado, J., Silva, P.C., Skog, J.E., Wiersema, J.H., Turland, N.J., 2006. International Code of Botanical Nomenclature (Vienna Code) Adopted by the Seventeenth International Botanical Congress, Vienna, Austria. Regnum Vegetabile 146,1-568. A.R.G. Gantner Verlag KG.

Medlin, L.M., Priddle, J. (Eds.), 1990. Polar marine diatoms. British Antarctic Survey, U.K., 214 pp.

Mitomo, K., 1986. On the fossil diatoms in the Une Peat Bed, Yokoze-machi, Chichibu-gun, Saitama Prefecture, Japan. Bulletin of the Saitama Museum of Natural History 3, 31-44.

Mori, S., 1981. Diatom flora in the alluvial deposits underlying the Nohbi Plain, Central Japan. Bulletin of the Mizunami Fossil Museum 8, 127-138 (in Japanese with English abstract).

Naish, T., Powell, R., Levy, R., Wilson, G., Scherer, R., Tlarico, F., Krissek, L., Niessen, F., Pompilio, M., Wilson, T., Carter, L., DeConto, R., Huybers, P., McKay, R., Pollard, D., Ross, J., Winter, D., Barrett, P., Browne, G., Cody, R., Cowan, E., Crampton, J., Dunbar, G., Dunbar, N., Florindo, F, Gebhardt, C., Graham, I., Hannah, M., Hansaraj, D., Harwood, D., Helling, D., Henrys, S., Hinnov, L., Kuhn, G., Kyle, P., Läufer, A., Maffioli, P., Magens, D., Mandernack, K., McIntosh, W., Millan, C., Morin, R., Ohneiser, C., Paulsen, T., Persico, D., Raine, I., Reed, J., Riesselman, C., Sagnotti, L., Schmitt, D., Sjunneskog, C., Strong, P., Taviani, M., Vogel, S., Wilch, T., Williams, T., 2009. Obliquity-paced Pliocene West Antarctic ice sheet oscillations. Nature 458, 323-328. doi:10.1038/nature07867. 
Teraishi et al.

Nakatsuka, T., Watanabe, K., Handa, N., Matsumoto, E., Wada, E., 1995. Glacial to interglacial surface nutrient variations of Bering deep basins recorded by $\delta^{13} \mathrm{C}$ and $\delta^{15} \mathrm{~N}$ of sedimentary organic matter. Paleoceanography 10, 1047-1061. doi:10.1029/95PA02644.Okazaki, Y., Takahashi, K., Asahi, H., Katsuki, K., Hori, J., Yasuda, H., Sagawa, Y., Tokuyama, H., 2005. Productivity changes in the Bering Sea during the late Quaternary. Deep-Sea Research II 52, 2150-2162. doi:10.1016/j.dsr2.2005.07.003.

Oku, O., Kamatani, A., 1999. Resting spore formation and biochemical composition of the marine planktonic diatom Chaetoceros pseudocurvicetus in culture: ecological significance of decreased nucleotide content and activation of the xanthophylls cycle by resting spore formation. Marine Biology 135, 425-436. doi:10.1007/s002270050643.

Onodera, J., Takahashi, K. 2005. Silicoflagellate fluxes and environmental variations in the northwestern North Pacific during December 1997-May 2000. Deep-Sea Research I 52, 371-388. doi:10.1016/j.dsr.2004.10.001.

Onodera, J., Takahashi, K. 2012. Oceanographic conditions influencing silicoflagellate flux assemblages in the Bering Sea and subarctic Pacific Ocean during 1990-1994. Deep-Sea Research II, 61-64, 4-16. doi:10.1016/j.dsr2.2011.03.004.

Onodera, J., Stroynowski, Z.N., Nagatomo, R., Takahashi, K., Ravelo, C., Zarikian, C.A., in this volume. Diatom, silicoflagellate, and ebridian biostratigraphy at Hole U1341B, IODP Expedition 323. Deep-Sea Research II.

Poelchau, H.S., 1976. Distribution of Holocene silicoflagellates in North Pacific sediments. Micropaleontology 22, 164-193.

Pollard,D., DeConto, R.M., 2009. Modelling West Antarctic ice sheet growth and collapse through the past five million years. Nature 458, 329-332. doi:10.1038/nature07809.

Sancetta, C., 1982. Distribution of diatom species in surface sediments of the Bering and Okhotsk seas. Micropaleontology 28, 221-257.

Sancetta, C., Silvestri, S., 1986. Pliocene-Pleistocene evolution of the North Pacific ocean-atmosphere system, interpreted from fossil diatoms. Paleoceanography 1, 163-180. doi:10.1029/PA001i002p00163.

Scherer, R. P., Bohaty, S.M., Dunbar, R.B., Esper, O., Flores, J.-A., Gersonde, R., Harwood, D.M., Roberts, A.P., Taviani, M., 2008. Antarctic records of precession-paced insolation-driven warming during early Pleistocene Marine Isotope Stage 31. Geophysical Research Letters 35, L03505. doi:10.1029/2007GL032254.

Solomon, S., Qin, D., Manning, M., Marquis, M., Averyt, K., Tignor, M.M.B., Miller, H.L., Jr., Chen, Z. (Eds.), 2007. Climate Change 2007: The physical Science Basis: Cambridge (Cambridge Univ. Press). 
Teraishi et al.

Springer, A.M., McRoy, P.C., Flint, M.V., 1996. The Bering Sea Green Belt: shelf-edge processes and ecosystem production. Fisheries Oceanography 5, 205-223. doi: 10.1111/j.1365-2419.1996.tb00118.x.

Sreenivasa, M.R., Duthie, H.C., 1973. Diatom flora of the Grand River, Canada. Hydrobiologia 42, 161-224.

Stabeno, P.J., Schumacher, J.D., Ohtani, K., 1999. The physical oceanography of the Bering Sea. In: Loughlin, T.R., Ohtani, K. (Eds.), Dynamics of the Bering Sea: A Summary of Physical, Chemical, and Biological Characteristics, and a Synopsis of Research on the Bering Sea. Fairbanks (Univ. Alaska Sea Grant), 1-28.

Suto, I., 2003. Taxonomy of the marine diatom resting spore genera Dicladia Ehrenberg, Monocladia gen. nov. and Syndendrium Ehrenberg and their stratigraphic significance in Miocene strata. Diatom Research 18, 331-356. doi:10.1080/0269249x.2003.9705596.

Suto, I., 2004a. Taxonomy of the diatom resting spore genus Liradiscus Greville and its stratigraphic significance. Micropaleontology 50, 59-79.

Suto, I., 2004b. Dispinodiscus gen. nov., a new diatom resting spore genus from the North Pacific and Norwegian Sea. Diatom 20, 79-94.

Suto, I., 2004c. Coronodiscus gen. nov., a new diatom resting spore genus from the North Pacific and Norwegian Sea. Diatom 20, 95-104.

Suto, I., 2004d. Fossil marine diatom resting spore morpho-genus Gemellodiscus gen. nov. in the North Pacific and Norwegian Sea. Paleontological Research 8, 255-282. doi: 10.2517/prpsj.8.255.

Suto, I., 2004e. Fossil marine diatom resting spore morpho-genus Xanthiopyxis Ehrenberg in the North Pacific and Norwegian Sea. Paleontological Research 8, 283-310. doi: 10.2517/prpsj.8.283.

Suto, I., 2005a. Vallodiscus gen. nov., a new fossil resting spore morpho-genus related to the marine diatom genus Chaetoceros (Bacillariophyceae). Phycological Research 53, 11-29. doi: 10.1111/j.1440-183.2005.00369.x.

Suto, I., 2005b. Observations on the fossil resting spore morpho-genus Peripteropsis gen. nov. of marine diatom genus Chaetoceros (Bacillariophyceae) in the Norwegian Sea. Phycologia 44, 294-304. doi: 10.2216/0031-8884(2005)44[294:OOTFRS]2.0.CO;2.

Suto, I., 2005c. Taxonomy and biostratigraphy of the fossil marine diatom resting spore genera Dicladia Ehrenberg, Monocladia Suto and Syndendrium Ehrenberg in the North Pacific and Norwegian Sea. Diatom Research 20, 351-374. doi:10.1080/0269249x.2005.9705642.

Suto, I., 2006a. The explosive diversification of the diatom genus Chaetoceros across the 
Eocene/Oligocene and Oligocene/Miocene boundaries in the Norwegian Sea. Marine Micropaleontology 58, 259-269. doi:10.1016/j.marmicro.2005.11.004.

Suto, I., 2006b. Taxonomy of the fossil marine diatom resting spore morpho-genera Xanthioisthmus Suto gen. nov. and Quadrocistella Suto gen. nov. in the North Pacific and Norwegian Sea. Journal of Micropalaeontology 25, 3-22. doi:10.1144/jm.25.1.3.

Suto, I., 2006c. Truncatulus gen. nov., a new fossil resting spore morpho-genus related to the marine diatom genus Chaetoceros (Bacillariophyceae). Phycologia 45, 585-601. doi: 10.2216/04-91.1.

Suto, I., 2007. The Oligocene and Miocene record of the diatom resting spore genus Liradiscus Greville in the Norwegian Sea. Micropaleontology 53, 145-159.

Takahashi, K. 1987. Seasonal fluxes of silicoflagellates and Actiniscus in the subarctic Pacific during 1982-1984. Journal of Marine Research 45, 397-425. doi:10.1016/0198-0149(86)90022-1.

Takahashi, K., Jordan, R.W., Boltovskoy, D. (Eds.), 2005. Preface. Deep-Sea Research II 52, 2079. doi:10.1016/j.dsr2.2005.08.002.

Takahashi, K., Onodera, J., Katsuki, K., 2009. Significant populations of seven-sided Distephanus (Silicoflagellata) in the sea-ice covered environment of the central Arctic Ocean, summer 2004. Micropaleontology 55, 313-325.

Takahashi, K., A. C. Ravelo, C. A. Alvarez Zarikian and the IODP Expedition 323 Scientists. 2011. IODP Expedition 323 Pliocene and Pleistocene paleoceanographic changes in the Bering Sea. Scientific Drilling11, 4-13. doi:10.2204/iodp.sd.11.01.2011.

Tanaka, S., Takahashi, K., 2005. Late Quaternary paleoceanographic changes in the Bering Sea and the western subarctic Pacific based on radiolarian assemblages. Deep-Sea Research II 52, 2131-2149. doi:10.1016/j.dsr2.2005.07.002.

Trochim, A.R., Dooley, A.C., 2010. Diatom biostratigraphy and paleoecology of vertebrate-bearing Miocene localities in Virginia. Jeffersonian 23, Virginia Museum of Natural History, 1-18.

Yanagisawa, Y., 2010. Diatoms of the mudstone samples collected from the canyon wall of the Kushiro Submarine Canyon, northern Japan. Bulletin of the Geological Survey of Japan 61(3/4), 105-123.

Yanagisawa, Y., Akiba, F., 1998. Refined Neogene diatom biostratigraphy for the northwest Pacific around Japan, with an introduction of code numbers for selected diatom biohorizons. Journal of the Geological Society of Japan 104, 395-414. 
Teraishi et al.

\section{Legends}

Fig. 1. Map illustrating the sites drilled during the Integrated Ocean Drilling Program (IODP) Expedition 323 (Sites U1339-U1345), Deep Sea Drilling Project (DSDP) Leg 19 (Sites 183-192), Ocean Drilling Program (ODP) Leg 145 (Sites 882, 884 and 887) and the piston cores from the Lamont-Doherty repository (V20-107, RC-216) with the surface water circulation modified after Creager et al. (1973), Stabeno et al. (1999), Haug et al. (2005), Kamikuri et al. (2007) and Expedition 323 Scientists (2011a). The Alaskan Stream, East Kamchatka Current, Bering Slope Current (BSC), and Aleutian North Slope Current (ANSC) are indicated.

Fig. 2. Relative abundance (\%) of diatom, silicoflagellate and ebridian biostratigraphic markers from the IODP Expedition 323 Hole U1343E. Diatom zones and NPD codes are from Yanagisawa and Akiba (1998). Silicoflagellate and ebridian zones are from Ling (1973).

Fig. 3. Selected paleoenvironmental diatom indicators in total diatom assemblages from the IODP Expedition 323 Hole U1343E as well as changes of fossil Chaetoceros resting spores valve numbers per 400 valves of other diatoms with fluctuations of resting spore assemblages in morpho-generic level. Solid and dashed lines in the diatom fluctuations show the relative abundance (\%) and the running means at 5 point, respectively. The age model is Asahi et al. (in this volume). The boundary age of marine isotope stages (Lisiecki and Raymo, 2005) are from http://lorraine-lisiecki.com/LR04_MISboundaries.txt.

Fig. 4. Selected biostratigraphic useful diatoms (1-6) and silicoflagellates (7-10) from IODP Expedition 323 Hole U1343E. Scale bar $=10 \mu \mathrm{m}$. 1. Actinocyclus ochotensis Jousé, Sample 323-U1343E-81X-5W, 146-148 cm. 2. Neodenticula koizumii Akiba et Yanagisawa, Sample 323-U1343E-72X-3W, $132-134 \mathrm{~cm}$. 3. Neodenticula seminae (Simonsen et Kanaya) Akiba et Yanagisawa, Sample 323-U1343E-1H-3W, 146-148 cm. 4. Proboscia curvirostris (Jousé) Jordan et Priddle, Sample 323-U1343E-17H-3W. 146-148 cm. 5. Stephanopyxis horridus Koizumi, Sample 323-U1343E-64X-3W, 146-148 cm. 6. Thalassiosira jouseae Akiba, Sample 323-U1343E-8H-3W, 137-139 cm. 7. Dictyocha subarctios Ling, Sample 323-U1343E-29H-3W, 144-146 cm. 8, 9. Dictyocha spp., Sample 323-U1343E-32H-5W, 146-148 cm. 10. Distephanus medianoctisol Takahashi et al., Sample 323-U1343E-29H-3W, $144-146 \mathrm{~cm}$.

Fig. 5. Selected paleoenvironmental indicator diatoms from IODP Expedition 323 Hole 
U1343E. Scale bars $=10 \mu \mathrm{m}$ for figs. $1-5,7-18$ and $100 \mu \mathrm{m}$ for fig. 6. 1. Actinocyclus curvatulus Janisch in Schmidt et al., Sample 323-U1343E-11H-3W, $146-148 \mathrm{~cm}$. 2. A. ochotensis Jousé, Sample 323-U1343E-81X-5W, 146-148 cm. 3, 4. Bacterosira bathyomphala (Cleve) Syvertsen et Hasle in Hasle et Syvertsen, Sample 323-U1343E-1H-3W, 146-148 cm. 5. Coscinodiscus marginatus Ehrenberg, Sample 323-U1343E-64X-3W, 146-148 cm. 6. C. oculus-iridis Ehrenberg, Sample 323-U1343E-26H-3W, 146-148 cm. 7. Fragilariopsis cylindrus (Grunow) Frenguelli, Sample 323-U1343E-24H-3W, 120-122 cm. 8. F. oceanica (Cleve) Hasle, Sample 323-U1343E-2H-5W, 146-148 cm. 9. Paralia sulcata (Ehrenberg) Cleve, Sample 323-U1343E-1H-3W, 146-148 cm. 10. Porosira glacialis (Grunow) E. Jørgensen, Sample 323-U1343E-17H-3W, 146-148 cm. 11. Rhizosolenia hebetata J.W. Bailey, Sample 323-U1343E-9H-4W, 124-126 cm. 12. Shionodiscus trifultus (G. Fryxell) A.J. Alverson et al., Sample 323-U1343E-2H-5W, 146-148 cm. 13. Stephanopyxis turris (Greville et Arnott) Ralfs in Pritchard, Sample 323-U1343E-82X-5W, 146-148 cm. 14. Thalassiosira antarctica Comber, Sample 323-U1343E-2H-5W, 146-148 cm. 15. T. hyalina (Grunow in Cleve et Grunow) Gran, Sample 323-U1343E-1H-3W, 146-148 cm. 16. T. nordenskioeldii Cleve, Sample 323-U1343E-73X-3W, 146-148 cm. 17. Gemellodiscus cingulus var. cingulus Suto, Sample 323-U1343E-53X-3W, 106-108cm. 18. G. cingulus var. longus Suto, Sample 323-U1343E-28H-3W, 145-147 cm.

Fig. 6. Time-series variation of silicoflagellates from the IODP Expedition 323 Hole U1343E. The age model is Asahi et al. (in this volume). The black dot represents the taxon presence instead of relative abundance, due to trace amount of encountered skeletons $(<10$ skeletons in total). The boundary age of marine isotope stages (Lisiecki and Raymo, 2005) are from http://lorraine-lisiecki.com/LR04_MISboundaries.txt.

Table 1. Datum events of diatoms, silicoflagellates and ebridian from IODP Expedition 323 Hole U1343E.

Appendix table 1. Stratigraphic occurrences of diatoms from IODP Expedition 323 Hole U1343E.

Appendix table 2. Stratigraphic occurrences of Chaetoceros resting spores from IODP Expedition 323 Hole U1343E.

Appendix table 3. Silicoflagellate and ebridian at Hole U1343E. The highlight with gray 
Teraishi et al.

color represents that the \% value is meaningless due to the trace amount of encountered skeletons.

Appendix table 4. Taxonomy list of diatoms, silicoflagellates and ebridians from the IODP Expedition 323 Hole U1343E. 


\section{Teraishi et al. (Fig. 1)}

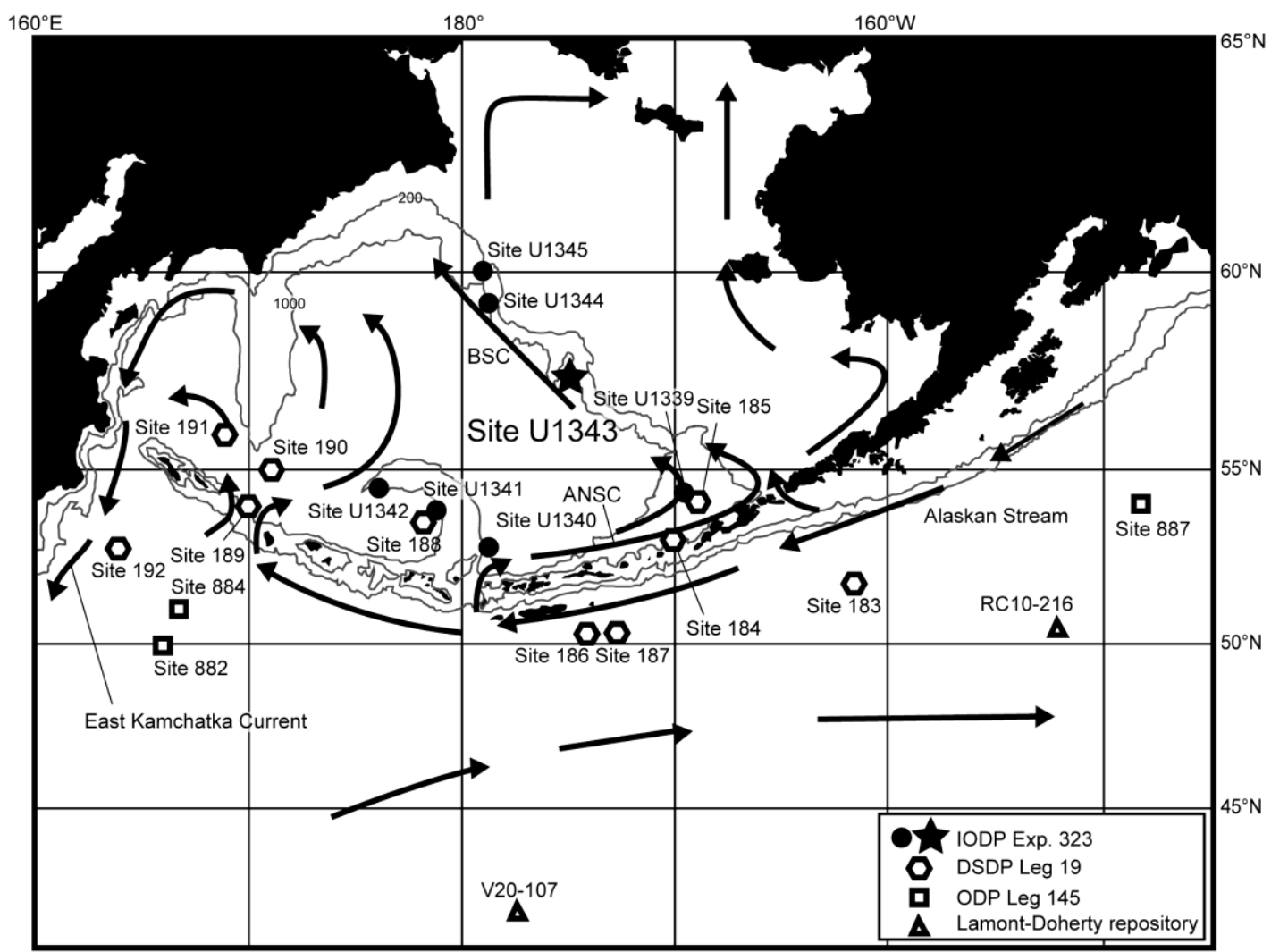

Fig. 1. Map illustrating the sites drilled during the Integrated Ocean Drilling Program (IODP) Expedition 323 (Sites U1339-U1345), Deep Sea Drilling Project (DSDP) Leg 19 (Sites 183-192), Ocean Drilling Program (ODP) Leg 145 (Sites 882, 884 and 887) and the piston cores from the Lamont-Doherty repository (V20-107, RC-216) with the surface water circulation modified after Creager et al. (1973), Stabeno et al. (1999), Haug et al. (2005), Kamikuri et al. (2007) and Expedition 323 Scientists (2011a). The Alaskan Stream, East Kamchatka Current, Bering Slope Current (BSC), and Aleutian North Slope Current (ANSC) are indicated. 
Teraishi et al.

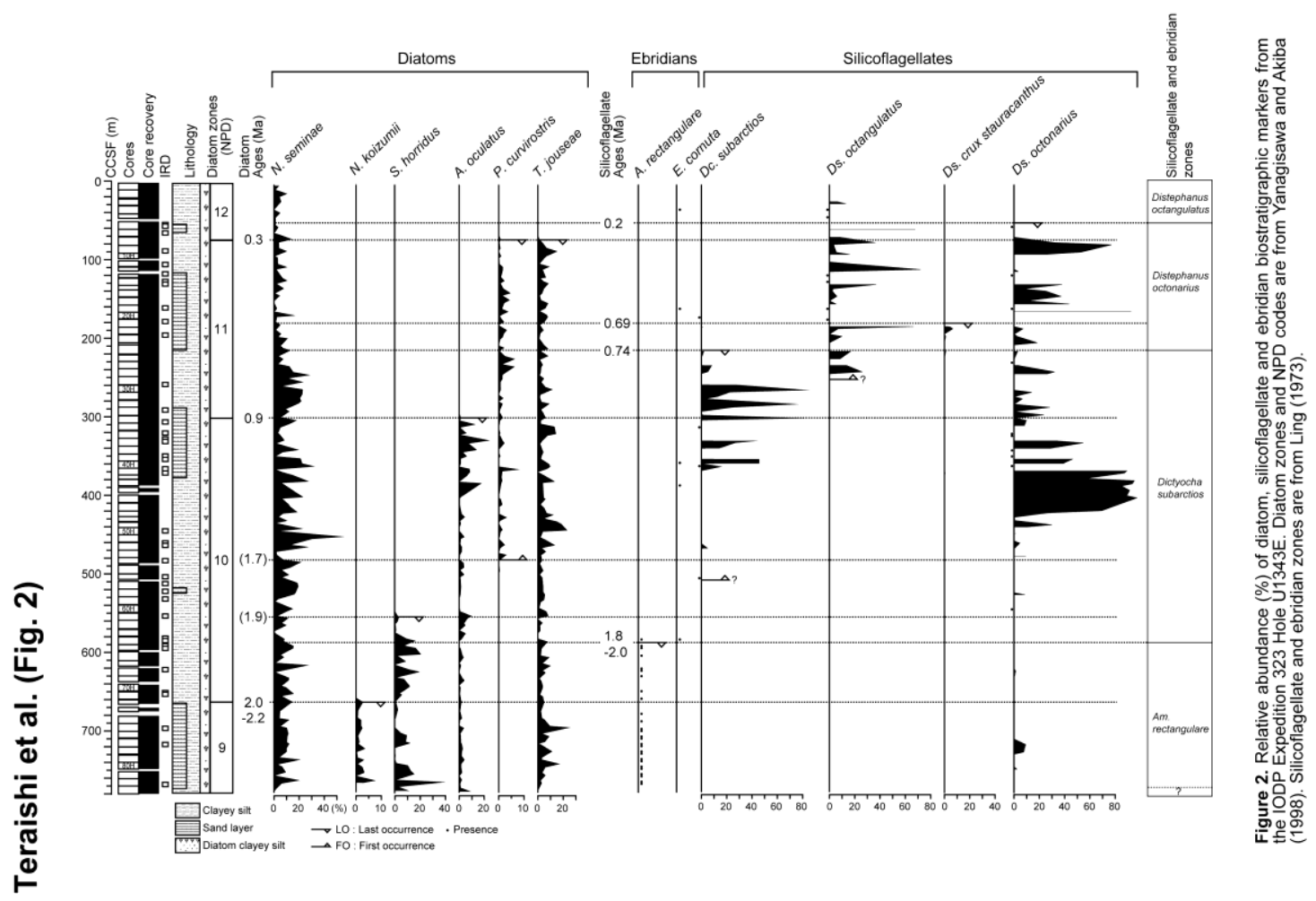


Teraishi et al.

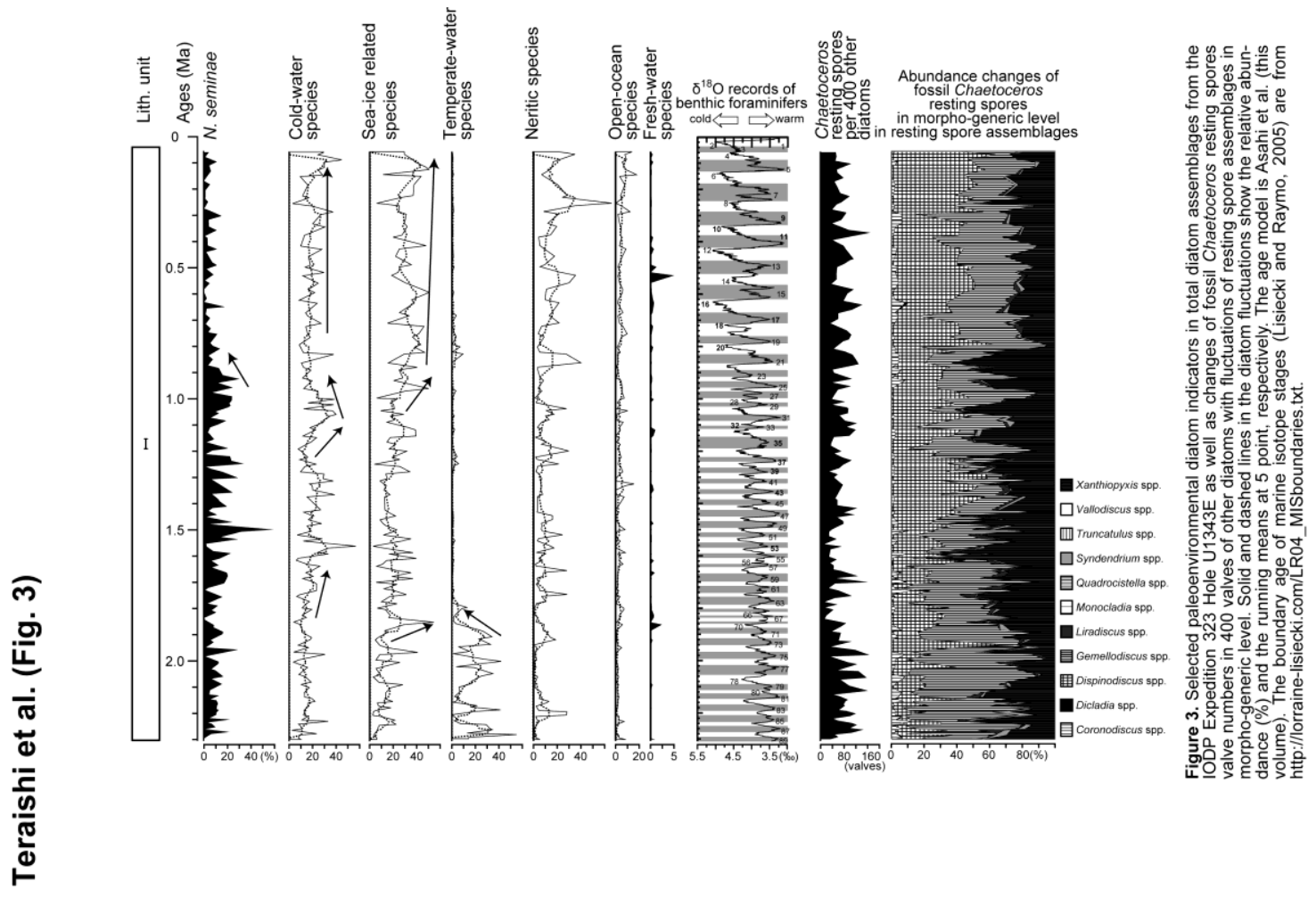


Teraishi et al.

\section{Teraishi et al. (Figure 4)}
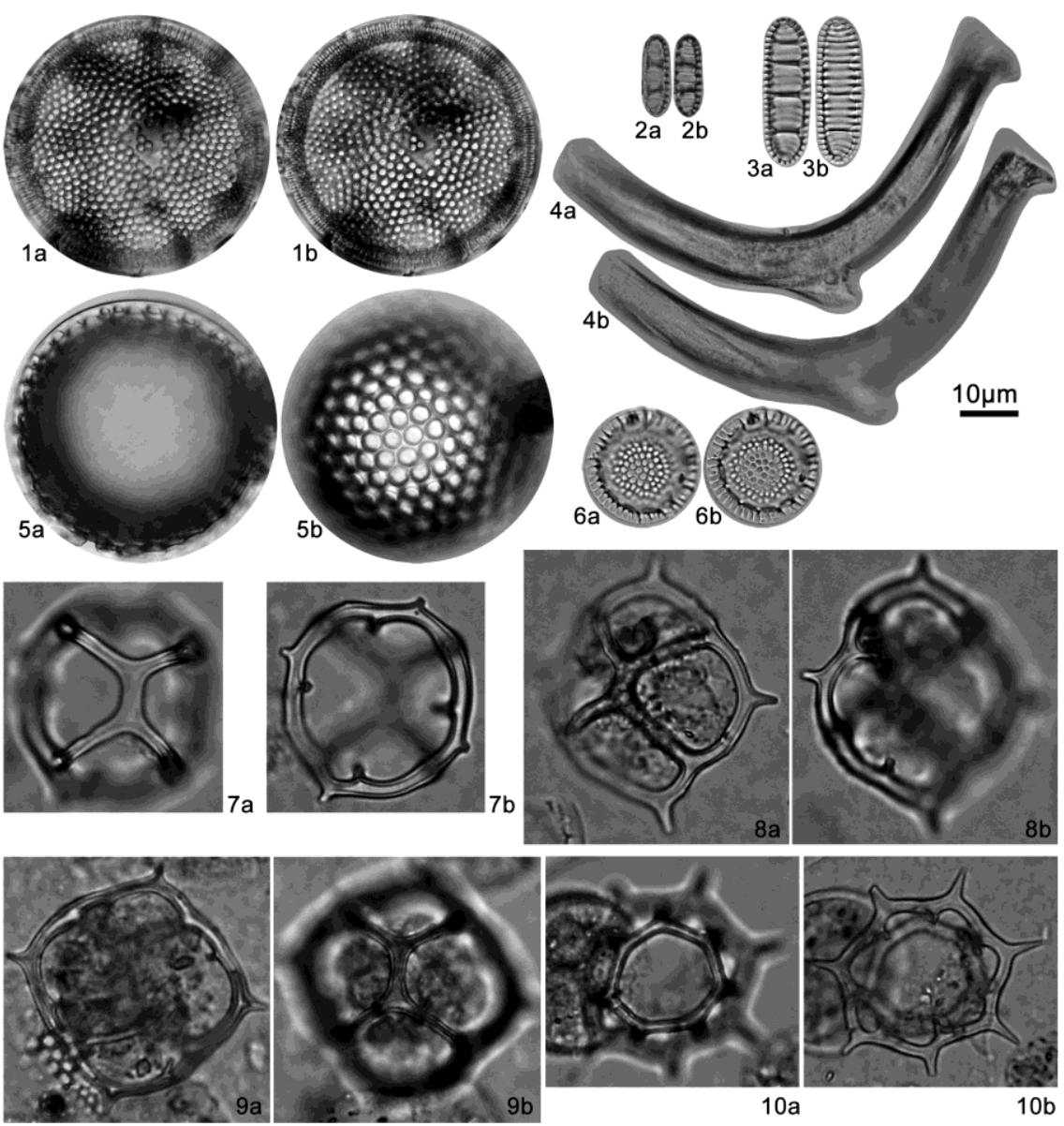

Fig. 4

Selected biostratigraphic useful diatoms (1-6) and silicoflagellates (7-10) from IODP Expedition 323 Hole U1343E. Scale bar $=10 \mu \mathrm{m} .1$. Actinocyclus oculatus Jousé, Sample 323-U1343E-81X$5 \mathrm{~W}, 146-148 \mathrm{~cm}$. 2. Neodenticula koizumii Akiba et Yanagisawa, Sample 323-U1343E-72X-3W, 132-134 cm. 3. Neodenticula seminae (Simonsen et Kanaya) Akiba et Yanagisawa, Sample 323U1343E-1H-3W, 146-148 cm. 4. Proboscia curvirostris (Jousé) Jordan et Priddle, Sample 323U1343E-17H-3W. 146-148 cm. 5. Stephanopyxis horridus Koizumi, Sample 323-U1343E-64X-3W. $146-148 \mathrm{~cm}$. 6. Thalassiosira jouseae Akiba, Sample 323-U1343E-8H-3W, $137-139 \mathrm{~cm}$. 7. Dictyocha subarctios Ling, Sample 323-U1343E-29H-3W, 144-146 cm. 8, 9. Dictyocha spp., Sample 323U1343E-32H-5W, 146-148 cm. 10. Distephanus medianoctisol Takahashi et al., Sample 323-U1343E$29 \mathrm{H}-3 \mathrm{~W}, 144-146 \mathrm{~cm}$. 
Teraishi et al.

Teraishi et al. (Figure 5)

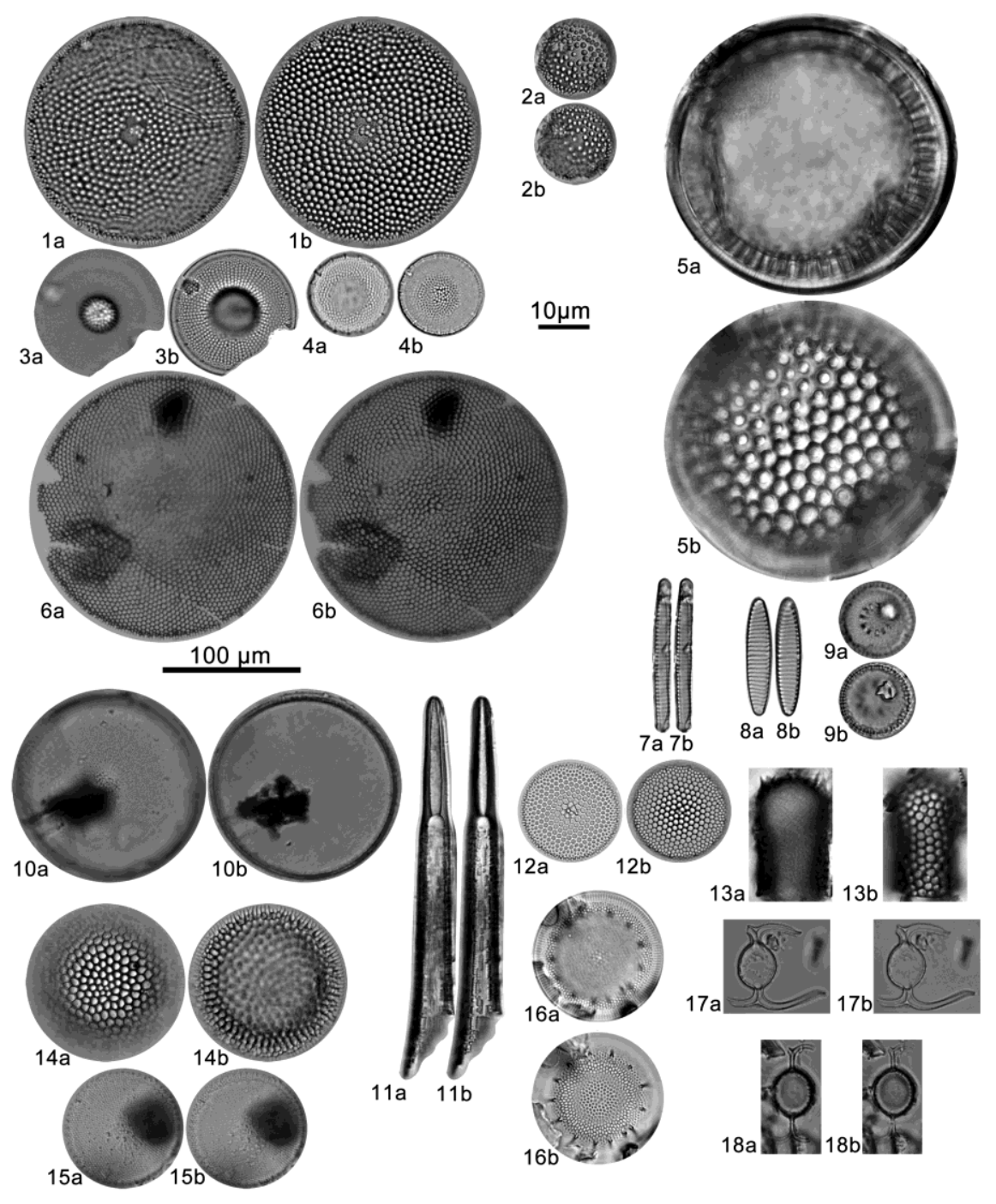

Fig. 5.

Selected paleoenvironmental indicator diatoms from IODP Expedition $323 \mathrm{Hole}$ U1343E. Scale bars $=10 \mu \mathrm{m}$ for figs. 1-5, 7-18 and $100 \mu \mathrm{m}$ for fig. 6.1. Actinocyclus curvatulus Janisch in Schmidt et al., Sample 323U1343E-11 H-3W, 146-148 cm. 2. A. ochotensis Jousé, Sample 323-U1343E-81X-5W, 146-148 cm. 3, 4. Bacterosira bathyomphala (Cleve) Syvertsen et Hasle in Hasle et Syvertsen, Sample 323-U1343E-1H-3W, 146$148 \mathrm{~cm}$. 5. Coscinodiscus marginatus Ehrenberg, Sample $323-\mathrm{U} 1343 \mathrm{E}-64 \mathrm{X}-3 \mathrm{~W}, 146-148 \mathrm{~cm}$. 6. C. oculusiridis Ehrenberg, Sample 323-U1343E-26H-3W, $146-148 \mathrm{~cm}$. . Fragilariopsis cylindrus (Grunow) Frenguelli, Sample 323-U1343E-24H-3W, 120-122 cm. 8. F. oceanica (Cleve) Hasle, Sample 323-U1343E-2H-5W, 146$148 \mathrm{~cm}$. 9. Paralia sulcata (Ehrenberg) Cleve, Sample $323-\mathrm{U} 1343 \mathrm{E}-1 \mathrm{H}-3 \mathrm{~W}, 146-148 \mathrm{~cm}$. 10. Porosira glacialis (Grunow) E. Jørgensen, Sample 323-U1343E-17H-3W, 146-148 cm. 11. Rhizosolenia hebetata J.W. Bailey, Sample 323-U1343E-9H-4W, 124-126 cm. 12. Shionodiscus trifultus (G. Fryxell) A.J. Alverson et al. Sample $323-\mathrm{U} 1343 \mathrm{E}-2 \mathrm{H}-5 \mathrm{~W}, 146-148 \mathrm{~cm}$. 13. Stephanopyxis turris (Greville et Arnott) Ralfs in Pritchard, Sample 323-U1343E-82X-5W, 146-148 cm. 14. Thalassiosira antarctica Comber, Sample 323-U1343E-2H$5 \mathrm{~W}, 146-148 \mathrm{~cm}$. 15. T. hyalina (Grunow in Cleve et Grunow) Gran, Sample 323-U1343E-1H-3W, 146-148 $\mathrm{cm}$. 16. T. nordenskioeldii Cleve, Sample 323-U1343E-73X-3W, 146-148 cm. 17. Gemellodiscus cingulus var. cingulus Suto, Sample $323-U 1343 \mathrm{E}-53 \mathrm{X}-3 \mathrm{~W}, 106-108 \mathrm{~cm}$. 18. G. cingulus var. Iongus Suto, Sample $323-\mathrm{U} 1343 \mathrm{E}-28 \mathrm{H}-3 \mathrm{~W}, 145-147 \mathrm{~cm}$. 
Teraishi et al.

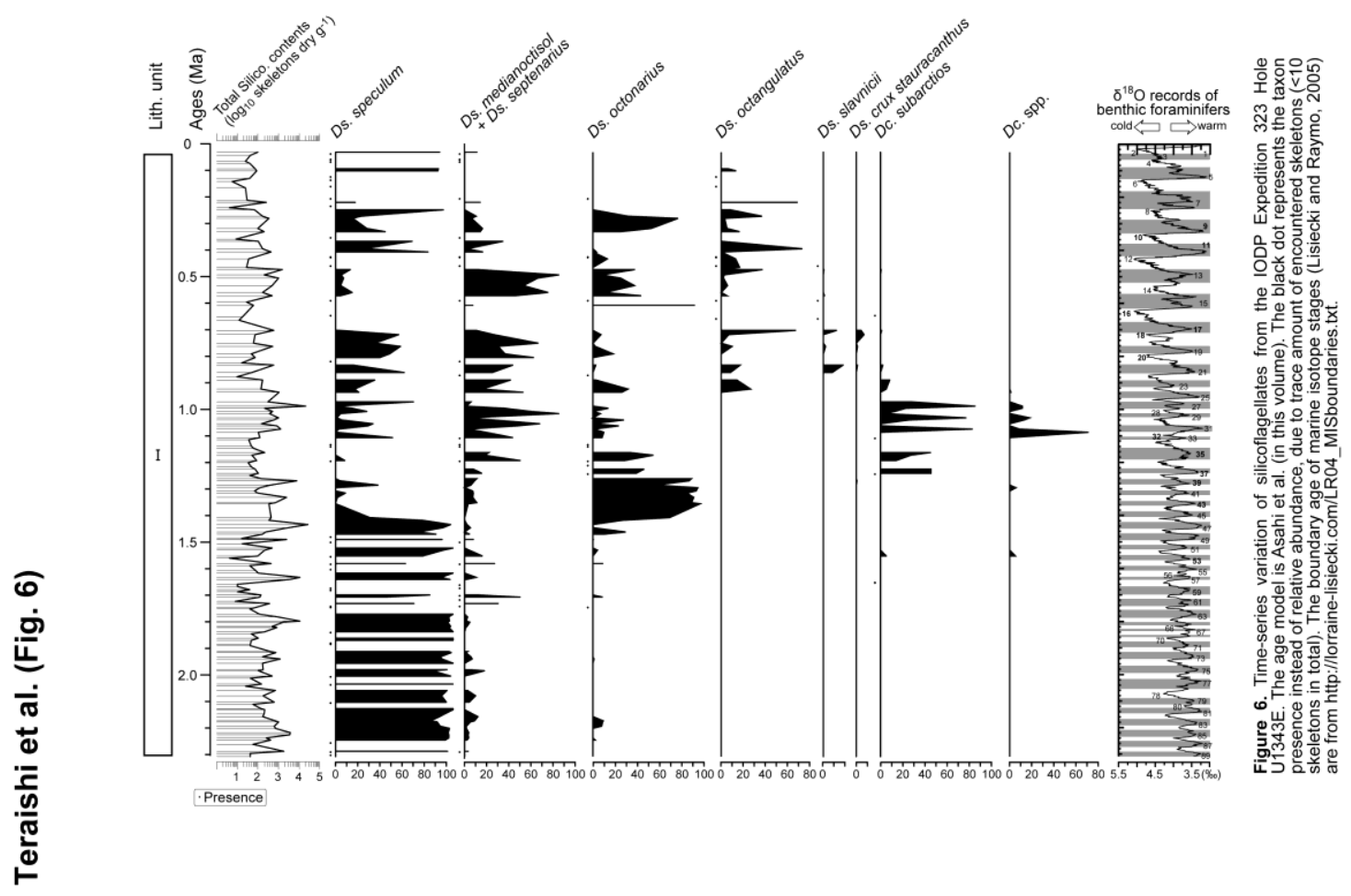




\begin{tabular}{|c|c|c|c|c|c|c|c|c|c|c|}
\hline \multirow{2}{*}{\multicolumn{2}{|c|}{ Datum events }} & \multirow{2}{*}{ Ages (Ma) } & \multicolumn{2}{|c|}{ Core, section, interval $(\mathrm{cm})$} & \multicolumn{3}{|c|}{ Depth CSF-A (m) } & \multicolumn{3}{|c|}{ Depth CCSF-A (m) } \\
\hline & & & Top & Bottom & Top & Bottom & Median & Top & Bottom & Median \\
\hline LO Distephanus octonarius & (s) & 0.2 & $5 \mathrm{H}-3 \mathrm{~W}, 146-148$ & $6 \mathrm{H}-3 \mathrm{~W}, 146-148$ & 41.17 & 50.67 & 45.92 & 46.54 & 59.09 & 52.815 \\
\hline LO Thalassiosira jouseae & (d) & 0.3 & $7 \mathrm{H}-3 \mathrm{~W}, 141-143$ & $7 \mathrm{H}-5 \mathrm{~W}, 136-138$ & 60.01 & 62.93 & 61.47 & 68.83 & 71.75 & 70.29 \\
\hline LO Proboscia curvirostris & (d) & 0.3 & $7 \mathrm{H}-3 \mathrm{~W}, 141-143$ & $7 \mathrm{H}-5 \mathrm{~W}, 136-138$ & 60.01 & 62.93 & 61.47 & 68.83 & 71.75 & 70.29 \\
\hline LO Ds. crux stauracanthus & (s) & 0.69 & $19 \mathrm{H}-5 \mathrm{~W}, 96-98$ & $20 \mathrm{H}-3 \mathrm{~W}, 121-123$ & 155.03 & 160.13 & 157.58 & 177.05 & 184.72 & 180.89 \\
\hline LO Dictyocha subarctios & (s) & 0.74 & $23 \mathrm{H}-3 \mathrm{~W}, 140-142$ & $23 \mathrm{H}-5 \mathrm{~W}, 53-55$ & 187.32 & 189.45 & 188.39 & 214.53 & 216.66 & 215.6 \\
\hline LCO Actinocyclus oculatus & (d) & 0.9 & $33 \mathrm{H}-5 \mathrm{~W}, 146-148$ & $34 \mathrm{H}-3 \mathrm{~W}, 146-148$ & 278.68 & 286.61 & 282.65 & 314.3 & 322.23 & 318.27 \\
\hline FO Proboschia curvirostris & (d) & 1.7 & $55 \mathrm{H}-3 \mathrm{X}, 146-148$ & $55 X-5 W, 132-134$ & 470.16 & 473.04 & 471.6 & 505.78 & 508.66 & 507.22 \\
\hline LO Stephanopyxis horridus & (d) & 1.9 & $60 X-5 W, 130-133$ & $61 X-3 W, 146-148$ & 521 & 527.78 & 524.39 & 556.62 & 563.4 & 560.01 \\
\hline LO Am. rectangulare & (e) & $1.8-2.0$ & $63 X-3 W, 146-148$ & $63 X-5 W, 146-148$ & 548.43 & 556.67 & 552.55 & 584.05 & 592.29 & 588.17 \\
\hline LO Neodenticula koizumii & (d) & $2.0-2.2$ & $71 \mathrm{H}-5 \mathrm{~W}, 128-130$ & $72 X-3 W, 132-134$ & 626.68 & 633.34 & 630.01 & 662.3 & 668.96 & 665.63 \\
\hline
\end{tabular}

